University of Michigan Law School

University of Michigan Law School Scholarship Repository

Law \& Economics Working Papers

$1-1-2013$

\title{
Why Y? Reflections on the Baucus Proposal
}

Reuven S. Avi-Yonah

University of Michigan Law School, aviyonah@umich.edu

Follow this and additional works at: https://repository.law.umich.edu/law_econ_current

Part of the Taxation-Transnational Commons

\section{Working Paper Citation}

Avi-Yonah, Reuven S., "Why Y? Reflections on the Baucus Proposal" (2013). Law \& Economics Working Papers. 84.

https://repository.law.umich.edu/law_econ_current/84

This Article is brought to you for free and open access by University of Michigan Law School Scholarship Repository. It has been accepted for inclusion in Law \& Economics Working Papers by an authorized administrator of University of Michigan Law School Scholarship Repository. For more information, please contact mlaw.repository@umich.edu. 


\section{Why Y? \\ Reflections on the Baucus Proposal}

\section{Reuven S. Avi-Yonah ${ }^{1}$}

The international tax reform proposal introduced by Sen. Max Baucus (D-MT) on November 19, 2013 contains several significant innovations that promise to define the terms of the debate for the foreseeable political future. It is therefore worth examining in detail even if it seems unlikely that progress toward meaningful reform can be achieved very soon.

The major component of the proposal is a move toward territoriality coupled with two alternative anti-profit shifting options, option $Y$ and option $Z$. This article will argue that option $Y$ represents a significant step forward and can be the basis of adopting a territorial regime, while option $Z$ is deeply flawed and risks further profit shifting unconstrained by the current limits on repatriating profits. Other important innovations in the Baucus proposal include a new destination based tax on Controlled Foreign Corporations (CFCs) on their sale of goods and services into the US; a major modification of the PFIC rules and other simplification measures; and a significant rollback of the portfolio interest exemption.

This article will analyze each of these elements of the proposal and then offer some suggestions for further improvement. The two major missing elements from the proposal are additional broad limitations on inbound base erosion and preventative measures against corporate expatriations.

\section{Option Y vs. Option Z.}

Both options $Y$ and $Z$ rely on an expansion of Subpart $F$ to prevent additional profit shifting that could result from the adoption of a territorial regime which completely exempts from US tax repatriated income that is not subject to either option. Absent such anti-profit shifting reforms, territoriality significantly exacerbates the risk of profit shifting because the main constraint against it, the problem of repatriating low tax foreign profits, will be gone. In addition, the imposition of a low $20 \%$ tax (payable in installments) on the accumulated two trillion dollars of unrepatriated profits currently held by US based MNEs overseas can be seen as rewarding past shifting behavior.

\footnotetext{
${ }^{1}$ Irwin I. Cohn Professor of Law, the University of Michigan. I would like to thank Mike Durst, Ed Kleinbard, and Lee Sheppard for helpful comments.
} 
Option $Y$ imposes a minimum tax set at $80 \%$ of the US tax rate on all foreign income of CFCs that is not earned on sales into the US (the latter are taxed in full as discussed below). The $80 \%$ tax rate is achieved by treating as Subpart $\mathrm{F}$ income all of the CFC's income that is subject to an effective foreign tax rate of less than $80 \%$ of the US rate, determined on the basis of US tax principles. This means that if the foreign effective rate is at the $80 \%$ threshold, then the income is not Subpart $F$ income and therefore exempt from further US tax under the general territoriality provision (subject to limitations regarding holding period and to not being deductible when distributed under foreign law). If the foreign tax rate is below the $80 \%$ threshold, the income becomes Subpart $\mathrm{F}$ income in full, but a credit is given for any foreign tax and a further deduction is granted for $20 \%$ of the deemed dividend. The net result is that all foreign income is subject to tax at a rate of at least $80 \%$ of the US rate. The US rate is not defined in the proposal but the general assumption will be that while this proposal is designed to be revenue neutral, other proposals advanced by Sen. Baucus (like new limits on depreciation) are intended to raise sufficient revenue to bring the US corporate rate down to $30 \%$ or less. If the new rate is $30 \%$ then option $Y$ means that all non US related foreign income of CFCs will be subject to tax at $24 \%$. No credit or deduction is allowed for foreign taxes on income that is not Subpart $F$ income and therefore exempt from US tax under the general rule, and some interest expense related to the exempt income is disallowed as well.

Under option Z, Subpart F income is defined to include $60 \%$ of the CFC's modified active income and $100 \%$ of its modified non-active income. Modified active income is defined as "active foreign market income", which is the aggregate of all items of income "attributable to economically significant activities with respect to a qualified trade or business" and derived in connection with goods sold for consumption or disposition outside the US or services provided outside the US with respect to persons or property located outside the US. "Economically significant activities" means activities performed outside the US by officers or employees who are part of the management and operational functions of the CFC and which make a substantial contribution to the production of the income. "Qualified trade or business" means manufacturing, producing, growing, or extracting property outside the US or providing services outside the US, including making a substantial contribution to a qualified trade or business.

Unlike option $Y$, option $Z$ does not directly take the foreign tax rate into account. However, it does retain the foreign tax credit for taxes attributable to 
Subpart $F$ inclusions, so that for the amounts subject to Subpart $F$ the foreign tax is creditable. Like option $\mathrm{Y}$, option $\mathrm{Z}$ disallows credit or deduction or exempt income and limits interest expense allocable to exempt income.

The following example illustrates the operation of options $Y$ and $Z$. A CFC has 100 in passive income that does not qualify for any exception under Subpart $F$ (the proposal retains the banking and insurance exceptions and the high tax exception of current law) subject to foreign tax at 0, 100 in active income from the manufacture and sale of widgets outside the US that is subject to foreign tax at 15, and 100 in active income from the provision of services outside the US that is subject to foreign tax at 25.

Under option $\mathrm{Y}$, the 100 of passive income is subject to US tax currently in full. The 100 of active manufacturing income is subject to US tax as well because the foreign tax rate of $15 \%$ is below $80 \%$ of the new US rate, which I assume to be $30 \%$. However, there is a deduction for $20 \%$ of this income, so that the US tax is $30 \%$ of 80 , or 24 , with a credit for 15 for a net US tax of 9 . The 100 of services income is not subject to US tax because the foreign tax rate exceeds $80 \%$ of the US tax rate so it is only subject to foreign tax at 25 . The total tax paid by the CFC on 300 of income is 40 to foreign countries and 39 to the US, or 79 , which is an overall effective tax rate of $26.3 \%$.

Under option Z, the 100 of passive income is likewise subject to US tax in full. The 100 of manufacturing income and the 100 of services income both qualify for the reduced Subpart $F$ inclusion at $60 \%$, and only $60 \%$ of the applicable foreign tax is creditable. Thus the parent includes 120 and gets a credit for 9 on the manufacturing income and 15 on the services income. The total tax paid by the CFC on 300 of income is 40 to foreign countries and $(220 * 30 \%$ 24 ) or 42 to the US, or 82 , which is an overall effective tax rate of $27.3 \%$.

Both options $Y$ and $Z$ tax US related income in full and both repeal check the box and the CFC look through rule, which are positive developments discussed below.

The main argument in favor of option $Z$ are that the test for "super active" foreign income is meaningfully tougher than current law active income and is designed to offer the lower rate only to income that has a strong economic nexus with the foreign jurisdiction. In addition, it is said that option $Y$ requires item by item calculation of foreign effective tax rates, which is too hard. 
However, I believe both of these arguments are misguided. First, while it is true that in the example above option $Z$ results in a higher overall tax rate than option $Y$, in many cases option $Z$ will result in no US tax while option $Y$ will result in some US tax. Specifically, consider a CFC that manufactures widgets in a foreign country for sale overseas and benefits from a foreign tax holiday. Option $Y$ will tax the resulting income at $24 \%$, because the foreign effective tax rate is zero. Option $Z$ will only tax $60 \%$ of the income, resulting in double non taxation of the other $40 \%$ which can be repatriated free of any tax. This is too strong an incentive to invest in real operations in foreign countries and too much encouragement for harmful tax competition.

In addition, I believe that super-active test can be manipulated. The definitions are far from clear. How senior do the foreign employees have to be? What does it mean that they will make a substantial contribution to the operations of the CFC? The adoption of the current substantial contribution test to avoid base company income is not helpful because that test has been notoriously abused. It strikes me that a Swiss "entrepreneur" that carries the "risk" while actual manufacturing is done by contract manufacturing affiliates and actual distribution by commissionaires is likely to qualify as super-active under this test, but this is precisely what the OECD BEPS project is designed to fight against. Option $Z$ strikes me as more of the same, and although a $60 \%$ inclusion is better than no inclusion under current law for this type of activity, the gap between the US rate of $30 \%$ and the foreign rate of $18 \%$ is too large not to encourage profit shifting.

Nor do I think that option $\mathrm{Y}$ is hard to administer. Every other major country with CFC rules takes the effective foreign tax rate into account, so that all of our trading partners have been living with this rule for years (as have we under the high tax kickout, which is retained under both options). Thus I do not believe that making these calculations is too hard. The major reason why EU MNEs have higher effective tax rates than US MNEs is that their CFC rules take the effective foreign tax rate into account, and we should not give up on this significant base protecting device. Subpart $F$ was originally designed only to grant deferral to income subject to a high foreign tax rate and option $\mathrm{Y}$ simply restores this rule for current conditions.

Finally, I think the distinction between active and passive income that underlies option $\mathrm{Z}$ is obsolete. As shown by the banking and insurance exceptions many types of CFCs earn income that would normally qualify as passive income, except that it is their active business income and therefore they get an exception even though the income is very mobile and hence not 
subject to any foreign tax. I would repeal these exceptions and subject banks and insurance companies to the same $80 \%$ test as all other CFCs, because in my mind the key question is not whether income is active or passive but whether it is subject to a high enough foreign tax rate to qualify for exemption without encouraging base erosion. Moreover, for most modern MNEs active income is as mobile as passive income so that it is very likely to go untaxed. The idea that real business operations should benefit from exemption because of competitiveness ignores the fact that competitiveness is determined by the overall tax rate of the CFC and not by the tax rate applicable to any particular business operation.

Some critics will no doubt argue that subjecting all foreign source income of US based MNEs to an effective tax rate of $24 \%$ will undermine US competitiveness, lead to inefficient foreign MNEs taking over operations from efficient US MNEs, and lead to corporate expatriations. But these critics ignore the context of the OECD BEPS initiative. EU based MNEs and Japanese MNEs already face effective overall tax rates that are higher than their US counterparts, despite having territoriality. If the US adopts option Y, they would all be happy to follow our lead, since they need the revenue more than we do and their population is clamoring for change more than ours. When the average nominal tax rate in the OECD is $24 \%$, imposing that rate on the foreign operations of US MNEs is not likely to damage US competitiveness. As for expatriations to low tax jurisdictions, that is a real danger that should be guarded against by the measures proposed below.

\section{The New Destination Based Tax.}

Both options $Y$ and $Z$ contain a major policy innovation that is very welcome. They impose US tax in full on any CFC that sells goods or services into the US market.

Both options include in Subpart F income US related income, which is the sum of imported property income and US services income. Imported property income is income from manufacturing, producing, growing or extracting, or selling or leasing, imported property. Imported property is property imported into the US by the CFC or a related person, but importantly it also includes property sold to unrelated persons if it was reasonable for the CFC or a related person to expect that the property would be imported or become a component of property that would be imported. The latter test is met if only the last sale of the property before import is to an unrelated person. Imported means the bringing of property into the US for use or consumption within the 
US, including granting rights to use intangibles or tangibles in the US. US services income is income derived in connection with services provided with respect to persons or property located within the US. It includes banking, financing and insurance or reinsurance of US risks.

This rule is the first time that a destination principle is applied under the income tax to sales into the US. It is designed to cover the obvious risk of a sale through a cost plus reseller located in a tax haven. The reasonable expectation of importation should be interpreted broadly to cover a situation in which two unrelated importers are interposed between the CFC and the US. Useful precedents can be found in the base company rules which depend on the location of sales outside the base company country of incorporation, in WTO origin rules, and in tort rules relating to the reasonable expectation that a product will be sold into the US. The services rule needs to be elaborated, and useful precedents can be found in the VAT context.

I have argued for twenty years that the best way for income taxes to overcome harmful tax competition is to rely more on taxation in the market jurisdiction because consumer markets are by definition not moveable. This is a very welcome step in the right direction.

The most interesting feature of this rule is that it ignores the obvious objection that the CFC does not have a PE in the US and therefore cannot normally be taxed if it is resident in a treaty country. Presumably the answer is that because it is a CFC we can ignore the treaty limitation since ultimately this is about enforcing US residence based taxation of the parent and not source based taxation of the CFC, and the PE rule is designed to limit source based taxation. But if we can do this type of override for CFCs, I think we should go further and apply the same rule to foreign MNEs as well, as long as their sales into the US exceed \$1 million. The PE threshold is obsolete and we should be in the forefront of modernizing it since we are the worlds biggest market jurisdiction.

This rule, together with the long overdue elimination of check the box and 954@(6), will go a long way to ensuring that US-based MNEs will pay tax on income economically earned in the US.

\section{Modernizing PFIC and other steps toward simplification.}

The Baucus proposal modernizes and simplifies the PFIC rules by applying a deemed interest amount to non marketable PFIC stock, defined as the AFR plus $5 \%$, and requiring mark to market for marketable stock. The provision 
also eliminates the passive asset test and reduces the passive income threshold to $60 \%$. These are welcome simplifications. It would be helpful to also add a de minimis exception since the rule is designed for rich shareholders.

The proposal also accelerates the worldwide allocation of interest expense, repeals the fair market value method for apportioning interest expense as too prone to manipulation and complexity, mandates that income attributable to a US PE is US source regardless of the title passage rule, repeals the dual consolidated loss rule, and repeals the indirect credit and section 909. These are likewise useful simplifications.

\section{Limiting the Portfolio Interest Exemption.}

The proposal eliminates the application of the portfolio interest exemption to corporate debt obligations. This is a very important step forward, and it leaves the exemption applicable only to bank account interest, interest on Treasuries, and interest on non corporate bonds, all of which are relatively negligible in the current rate environment. The proposal does not eliminate zero withholding on interest by treaty, and this distinction is important because treaties permit exchange of information, while the portfolio interest exemption applies to payments to tax havens. This provision goes a long way toward repairing the damage the US caused when it adopted the exemption in 1984, resulting in a race to the bottom. The usual vested interests will no doubt object that this will just increase the borrowing costs of US corporations, but in the context of the current drive toward automatic exchange of information and the EU savings directive, there is no reason to expect that similar reinstatement of withholding on interest to tax havens cannot be negotiated with our trading partners. This can be a bigger blow to tax evasion that even FATCA and the two can work in tandem to ensure that the 8 trillion dollars of untaxed interest income flowing around the world each year will finally be subject to taxation.

\section{Some additional provisions.}

The proposal includes a modest inbound anti base erosion provision dealing with conduits and hybrid instruments and entities, but this is in my opinion too narrow. We need a general application of the earnings stripping concept not just to interest but to royalties and cost of goods sold as well. There is no reason to tackle profit shifting and base erosion by US based MNEs forcefully 
under option $Y$ but leave foreign based MNEs relatively unscathed. Such a broad rule will no doubt raise some of the revenue we lose though territoriality.

The other major missing element in the proposal is addressing the new wave of corporate expatriations, which is mostly done through mergers with companies in low tax jurisdictions. We should adopt an exit tax though a deemed sale of assets of expatriating corporations and a real managed and controlled test for corporate residence (ie, one based on where the headquarters are and not on where the board meets). Otherwise we will risk losing more US based MNEs to low tax jurisdictions since those will continue to exist even if most of the OECD follows our lead on BEPS.

\section{Conclusion}

Overall, the Baucus proposal is a major step forward and could if adopted mark the beginning of a new era in international tax in which all MNEs pay their fair share. US based MNEs benefit from the protection of the US government and from multiple advantages resulting from their incorporation in the US. If taxation is the new social contract, it is time for the MNEs to bear their fair share of the cost of civilization. This proposal, and especially option $\mathrm{Y}$, goes a long way toward insuring that they do. 